\title{
Sapkın Vizör: Medyada Ölümün ve Ölü Bedenlerin Görsel Temsili ve Suriye İç Savaşı Örneği
}

\author{
Prof. Dr. Hüseyin KÖSE \\ Ar. Gör. Bahar BALCI
}

atatürk üniversitesi iletişim fakültesi, gazetecilik bölümü huseyink180@yahoo.com nişantaşı üniversitesi iktisadi

idari ve sosyal bilimler fakültesi, gazetecilik bölümü bahar.balci@nisantasi.edu.tr

\begin{abstract}
"Deviant Visor": Visual Presentation of Death and Dead Bodies in the Media and Civil War in Syria Case

"The dead body" as the most passive verb conjugation of live and death through his provocative portrayals in the media that transcend the boundaries of intimacy, give way to a change of perception on the human body in physical terms and on its meanings. When we consider that before, televisions and radios of the mourning houses were never opened to respect the dead, share the pain of the relatives of the deceased and not to harass the void left behind; the media's effort today to present death in bloody fashion by castrating the privacy of the dead body becomes even more significant. The fact that it is now impossible to think of the dramaturgy of pain without a stirring fiction requires us to place this issue at the center of the media's problematic representation of social reality. In this study, the visual representation of death and the dead body is analyzed in the context of photos published between 2011 and 2016 in Syria during the Civil War by benefiting from the semiotic approach of Roland Barthes and the content analysis method.
\end{abstract}

keywords: media, death, privacy, the representation of the dead bodies, the body ideology 


\section{Résumé}

\section{"Le viseur perverti": La représentation visuelle de la mort et des cadavres dans les médias et l'exemple de la guerre civile en Syrie}

"Le corps mort" en tant que la conjugaison la plus passive du verbe vivre et la mort à travers ses représentations provocatrices dans les médias qui dépassent les frontières de l'intimité, laissent place à un changement de perception sur le corps humain en termes physiques et sur ses significations. Quand on considère qu'auparavant, dans les maisons de deuil les postes de télévision ou les radios n'étaient jamais allumés pour respecter la mort, pour partager la douleur des proches du défunt et pour ne pas combler le vide laissé par lui, l'effort des médias d'aujourd'hui de présenter la mort de façon sanglante en castrant l'intimité des corps morts devient encore plus notable. Le fait qu'il est maintenant impossible de penser sur la dramaturgie de la douleur sans une fiction agitatrice nous exige sans doute de placer ce sujet au centre de la représentation problématique de la réalité sociale par les médias. Dans cette étude, la représentation visuelle de la mort et du corps mort est analysée dans le contexte des photos prises entre 2011 et 2016 en Syrie pendant la Guerre Civile en bénéficiant de l'approche sémiotique de Roland Barthes et de la méthode d'analyse du contenu.

mots-clés: média, mort, intimité, représentation de cadavres, idéologie du corps

\section{Öz}

Yaşamın en pasif fiil çekimi olan "ölü beden"in ve haber fotoğraflarındaki kışkırtıcı sunum biçimleriyle birlikte de ölümün mahremiyet eşiği aşılmış, fiziksel anlamda bedenin algılanışı ve içerdiği anlamlar büyük ölçüde değişmiştir. Bir zamanlar matem/yas evinin televizyon ve radyoları, ölüme duyulan saygı gereğince belli bir süre için -ölenin yakınlarının acısını paylaşmak ve gidenin ardında bıraktığı boşluğu taciz etmemek için- hiç açılmazken, günümüzde medyanın ölümü ve ölü bedenlerin mahremiyetini iğdiş edercesine kanlı görüntüler eşliğinde gözlere sokma çabası oldukça manidardır. Acının dramaturjisinin, ajitatif bir kurgu olmadan düşünülemez hale getirilmesi ise, konuyu medyanın sorunlu toplumsal gerçeklik temsilinin odağına taşımayı gerektirmekte kaçınılmaz olarak. Bu çalışmada, ölümün ve ölü bedenin görsel temsili konusu Suriye iç Savaşı'nın 2011-2016 yılları arasında yayımlanan fotoğrafları bağlamında değerlendirilecektir. Çalışmada Roland Barthes'ın göstergebilim yaklaşımı ile içerik analizi yönteminden yararlanılacaktır.

anahtar kelimeler: medya, ölüm, mahremiyet, ölü bedenlerin temsili, beden ideolojisi 
"Ölmek üzere olan kişiye yalnızca hayatta kalanların dilini sunabiliriz." Zygmunt Bauman

\section{Giriş}

Fotoğrafçıı̆̆ın özü, başlangıçta somut gerçekliğin dolaysızca objektife yansıtılmasından ibaretti. Kısa süre sonra fark edildi ki, fotoğrafın kaydettiği ışık her ne kadar "gerçeğin izi" varsayılsa da, içinde barındırdığı kimi ideolojik bakış açılarının kıyıcılığı, fotoğrafçılık mesleğinin olgusal gerçeklik karşısında daha "mesafeli" ya da "tarafsız" bir kimliğe sahip olmasına yetmemekteydi. Tarafsızlık ve dengelilik, özellikle gazetecilik mesleğinin önemli alt türlerinden birisi olan savaş muhabirliği dikkate alındığında, en hayati mesleki ilkelerden biriydi ve ölüme ve ölen kişinin bedensel mahremiyetine yapılan dolaysız tanıklığın, ölüm olgusunun mevcut anlamının yolundan saptırıması bakımından öngörülmemiş yıkıcılıkta sonuçları olabiliyordu. Ölümün vuku bulduğu coğrafyaların veya ölen kişilerin ulusal, etnik, dinsel, cinsel ve sosyo-ekonomik kökenlerinin baskın göstergeler olarak öne çıktığı durumlarda ise, savaş gazeteciliğinin gerçekliğin katlini de aşan ölçülerde, daha genel, çarpıtılmış ve "çarpıtan" bir ideolojisinden de söz edilebilirdi üstelik. Bu açıdan bakıldığında, ölümün saygınlığı yaşayanın saygınlığına eşdeğerdi ve eğer ölen kişi gözle görülür biçimde etnik, dinsel ve toplumsal statüsünün düşüklüğüne yapılmış bir vurguyla ön plana çıkarılıyorsa, ölümünün de müptezel bir terkiple sonuçlanması mukadderdi. Gerçekten de öyleydi; pratikteki durum, insan haklarına duyarlı bir yayıncılığın ideal norm ve ölçütlerinin çok uzağındaydı. Çok genel bir belirleme çok basit olarak şu biçimde formüle edilebilirdi: Batı'nın yaşam standardının, teknik ve bilimsel kapasitesinin, sivil ve demokratik kültürel düzeyinin üstünlüğü ile onu karşı kutupta pervasızca olumsuzlayan, türlü dezavantajlara sahip bir Doğu dünyasının söz konusu kriterler bakımından ifade ettiği gerilik, kaçınılmaz olarak her iki dünyanın ölüm tasvirlerine de dolaysız biçimde nüfuz etmişti. Gerçekten de, en azından normatif olarak, gazetecilik mesleğini icra edenlerin ve elbette savaş fotoğrafçılı̆̆ı yapan gazetecilerin de "gerçeğin yansız görüntüsü"nden başka yanlarında taşıyacakları bir silahları olmamalı yönündeki düsturun hakkıyla yerini bulduğundan söz edilemezdi. Çünkü savaşın kendisi -hep söylenegeldiği gibi- başlı başına bir hakikat katli aracıydı ve hele de gazetecinin savaşan taraflardan birine dolaysız mensubiyetinden söz edilmekteyse, bu durum işleri daha da içinden çıkılmaz bir hale getirmekteydi.

Meseleye daha genel bir zaviyeden, yani haber medyasının mutat retoriği ve yaygın sunum tarzı açısından bakıldığında da durum pek fazla değişmiyordu: Bedenin mahremiyetine bir de ölü bedenin mahremiyeti ve medyanın bu kırılgan mahremiyete yönelik saplantılı ve marazi tavrı eklendiğinde, ortaya fotoğraf etiği ve gazetecinin tarafsızlığı konularını da aşan bir insanlık dramı çıkmaktaydı ki, bu dramı insanlık onurunun selameti açısından açıklığa kavuşturmak bugün için daha da hayati bir önem taşımaktadır. Konuya medya etiği açısından bakıldığında 
ise, hiç kuşkusuz öznel yargılardan ve hislerden sıyrılamayıp ölümü tarafı bir biçimde belgelemenin, ölümün dolaysız tanığı olan fotoğrafın çoğalttığı imgeleri belli amaçlarla dünyanın dört bir köşesine yaymanın -gazetecilik mesleği aracılığıyla- gazetecilik alanına ödettiği bedeller çok yüksektir. Ulusal ve küresel ölçekli gazetecilikte kurbanların mahremiyet alanlarının korunması yönünde verilmiş sözün bir türlü tutulamamasının ekonomi-politik nitelikli birçok açık-gizli nedeni vardır kuşkusuz. Meseleye mesleğin genel işleyiş dinamikleri açııından bakıldığında ise, temel problemin güç-iktidar-söylem ilişkisinin etkili görsel malzemeyle birleştiği noktada şekillenen bir dramaturjiden kaynaklandığı muhakkaktır.

Çok özet olarak söylersek, yoksulların ve madunların egemen medya retoriği açısından mahremiyetlerinin bir geçerlik hükmü yokken, daha ayrıcalıklı kesimlerin ölü imgelerinin mahremiyetlerinin bile ölümcül bir (haber) değeri vardır. Tıpkı varsıl kesimlerin mezarlarının yoksullarınkine oranla daha korunaklı ve kitlesel bir uzaklığa sahip olması gibi. Dolayısıyla yoksullara ait ölüm imgeleri kamusal alana fütursuzca servis edilirken, zengin ve ayrıcalıklı kesiminki gözlerden olabildiğince uzak tutulur. Öte yandan, gerek güç ilişkileri, gerekse ticari liberal medyanın acımasız reyting savaşı nedeniyle haberin değerini ölen insan sayısı ve dökülen kanın miktarıyla ölçen habercilik standardının umulanın ötesinde rağbet görmeye başlamasının da yerleşik toplumsal ahlakın sözde erdemlerine ilişkin söylediği önemli şeyler vardır. Kadim ölüm gerçeğine duyuları körelmiş bir tanıklığın topluca deneyimlenen vahametidir bu tam da. Elbette bu körelmiş kamusal algıyı kuran şey, medya retoriğinden başkası değildir. Sadece ölüm imgelerinin ve ölü bedenlerin uluorta teşhiri değil, savaş gazeteciliği dışındaki diğer tüm medya içeriklerinde de ölümün iffet ve mahremiyetinin fütursuzca iğdiş edildiğine tanık olmaktayız her dakika. Öyle ki, yazılı ve görsel medya organlarında kaldırımayı bekleyen cenazeler yas ve yeis sömürüsünün en sofistike biçimleri ve pornografik bir bakış açısıyla ele alınırken, ölen kişinin ardından hissedilen ölümün sızısını en silik tonlarına kadar incelten sunum örnekleri, reytingi düştüğü zamanlarda bile popülaritesinden hiçbir şey kaybetmemektedir. Toplumsal gerçeklik ölü bedenin mahremiyetini onaylasa da, ticari yayıncılığın her türlü deontolojik "etik" tavra galebe çalan faydacı yasaları bu algı çerçevesini korumaya yetmemektedir. En yoğun acılardan ve ölümün içinden devşirilmiş, seyirlik düzeyi yüksek "malzemeler" üretilmesinden de bellidir ki, vuku bulan ölümlerin resmi ve gayrı resmi sorumlularının zaptını tutması beklenen medya mensupları adeta ölümün şarlatanlığını ve reklamını yapmakta birbirleriyle yarış etmektedirler. Üstelik bu ve benzeri fütursuzluk içeren saiklerle, Facebook, Twitter, YouTube gibi bazı sosyal medya mecralarında neredeyse ölümü "beğenir" bir toplum yaratılmakta, ölü bedenler ve bizatihi ölümün kendisi medya tarafından seyirlik değeri yüksek bir "malzeme" olarak kodlandıkça, ölüme bahşedilen metafizik, teolojik ve mistik değer gitgide aleladeleşerek sıradanlaşmaktadır. Ölüm, ederi yüksek bir teşhir ürünü haline geldikçe, ihtiva ettiği kutsallıktan da süratle arındırımaktadır. Oysaki tarih boyunca ölüme ve ölüye gösterilen ihtimam her zaman baki kalmıştır. Eskiden ölülerin defin işlemi sırasında yapılan merasimlerde yuğcu adı verilen 
kişiler ölenin maceralarını hikâye edip anlatıllarken, sığıtçı adlı kişilerin de ağlayıcııık görevini yerine getirdikleri bilinirdi (Onay, 2013, s. 582). Şimdilerde ise, sığıtçının görevini medya üstlenmiş görünmektedir. Atalarımız mağara duvarlarına ilk büyüsel çizimleri nakşederken yaşam-ölüm döngüsünü de tasvir etmekteydiler. Şimdilerde ise yaşamsal anın her kesitinin ve ölümün tasvir edilişi dijital teknolojik çağın sunduğu devrim niteliğindeki olanaklarla büyük merhaleler kaydetmiş bulunuyor. Bu süreçte haber fotoğrafçıları ve kameramanları da en güçlü silahları olan fotoğraf makinalarını ve kameralarını kullanarak ölümü adeta yok ederek "ölümsüzleştirdiler". Hatta biyolojik olarak yok olan bedenin yerine yeni cyborg (siber organizma) bedenler inşa ettiler. Ölen kişinin mazisine ilişkin en eski yaşamsal kesitten başlayarak ölümüne dek uzanan zamansal sürecin dilsiz biyografisinin yolunu fotoğraflarla döşeyerek oluşturdukları galerilerle kıymeti kendinden menkul yeni bir ölüm mitologyası yarattılar.

Bu çalışmada, bu mitologyanın sorunlu içeriği ve ima ettiği anlamlar, ticari medya retoriği yoluyla ölümün peyderpey demistifiye edilişi, gözden düşüşü ve sonrasında metalaşması sorunu bağlamında ele alınarak, görsel olarak ölü bedenlere yer veren haber sunum örnekleri üzerinden tartışılmaya çalışılacaktır.

\section{Medyada Ölümün Seyirlik Bir Değer Olarak Kodlanışı}

Yürürlükteki egemen gazetecilik pratiği bağlamında, üzeri gazete sayfaları ile örtülmüş bir ceset görüntüsünün hemen yanı başına kanlar içindeki bir yaralının fotoğrafının iliştirilmesinin "ses getirecek" bir sayfa düzeni ve kurgusu veya gerçeklik dramaturjisi oluşturduğu aşikârdır. Ancak aynı görüntünün gerek meslek etiği ve ilkeleri, gerekse çiğnenen insanlık onurunun aldığı hayati yaralar açısından tamiri imkânsız bir yıkım olduğu da bir gerçektir. Ne var ki, yazılı ve görsel medya bu hakikati hemen her zaman göz ardı ederek, sadece ölü bedenin değil, aynı zamanda onu sonsuzluğa uğurlayan cenaze ritüelinin de mahrem sınırlarını aşan türden yayımlar yapmakta bir beis görmemekte, icra ettiği sorunlu sunum tarzının kaçınılmaz sonucu olarak, yaygın kamusal algıda ölüm olgusuna yönelik ciddi körelmelere yol açmaktadır. Dahası, ölümün kendisi de diğer pek çok kültürel gösterge gibi, bir meta olarak tüketilmektedir. Adorno ve Horkheimer'ın kehanetleri adeta doğrulanmaktadır: "Fanilik ve tüketim ekseninde endüstri toplumunun tahakkümü insanlarda artık temelli etkili olacaktır. Kültür endüstrisi ürünleri, insanlar perişan halde olsalar bile, hazcı bir biçimde tüketilecektir" (2010, s. 170). Benzer bir tüketim, insan mahremiyetinin en kırılgan en perişan imgesi olan ölüm konusunda da geçerlidir. Medya yoluyla insanlar ölümü ve ölü beden görüntülerini hazcı bir iştahla tüketirlerken, aynı zamanda ölümün içerdiği son derecede kırılgan mahremiyeti de iğdiş etmektedirler. Deyim yerindeyse, artık ölümün mahremiyeti, paylaşılan ve vicdandan önce göze seslenen görüntüden beslenen bir metaya dönüşmüştür.

Eskiden göze değil de kafaya seslenen ve içeriği zenginleştiren ikincil bir öğe niteliğindeki medya görselleri (Topuz, 2003, s. 413), günümüzde realiteyi 
tanımlayan birincil unsura dönüşmüştür. Kuşkusuz gözle kavrayıp düşünme çağında olduğumuz anlamına gelir bu. Ölümün içerdiği dehşetin içinin boşaltılması, onun sıradanlaşmasıdır aynı zamanda; ve elbette sıradanlaşan her şey gibi, kolay "erişilebilir" ve tüketilebilir olması... Televizyon yayınlarında şiddetin zirveye ulaştığı anların değişmez ve bilinen sonu, genellikle ölüm anlarıdır. Haberler de dâhil olmak üzere, reality show'larda, dizi ve filmlerde şiddetin her türü öylesine yoğun biçimde işlenmektedir ki, ölümün olmadığı sonlar, ortalama izleyicinin beklentisini karşılamaz bile. Şiddet içeriğinin yoğun işlendiği programlarda şayet ölüm sıradanlaşmışsa, bu süreçte ası önemli olan, ölümün postmortem (ölüm sonrası) düzeyine erişmesi olmuştur kuşkusuz. Haluk Şahin'in de deyimiyle, bu süreçte, "azalan fayda yasası" gereğince, her seferinde bir öncekinden daha fazla şiddet içeren, daha kanlı ve vahşi öldürme sahneleri dramatik bir kurgu içinde tekrar edilip durmaktadır. Her şiddet eylemi, daha fazla şiddeti çağırmaktadır (2014, s. 67). Bu çağrıya hemen her zaman olumlu yanıt veren izleyici ise, bu çarkın sürdürülmesinin asli belirleyenidir. Böylece ölümün medyatik gösterisi son hız sürmektedir.

Barthes'ın ölümün ve ölülerin fotoğraflanması ile ilgili tespitleri de aynı şekilde ürperti vericidir. Barthes'a göre, fotoğraflanan kişinin kamera karşısındaki varlığı asla metaforik olamaz. Fotoğrafın kanıtladığı bir şey varsa, o da fotoğraftaki kişinin o belirli anda, oradaki varlığıdır. Ölü fotoğraflarını korkunçlaştıran da budur: fotoğrafın sunduğu "gerçek" ve "canlı" kavramları arasında yaşanan kafa karışıklığı. Fotoğraf bir yandan fotoğraftakinin gerçek ve dolayısıyla canlı olduğunu öne sürerken, bir yandan da bu gerçeği geçmişe kaydırarak "bu vardı, ama artık yok" duygusunu ve "ölü olduğunu" öne sürer zımni olarak. Bu anlamda, ölmüş kişilerin fotoğraflarını korkunçlaştıran şey, Barthes'ın deyişiyle, "fotoğrafın cesedin ceset olarak canlı olduğunu onaylamasıdır. Bu ölü bir şeyin yaşayan görüntüsüdür" (1992, s.97-98). Bu yüzden de ölü bedenler fotoğraflandıklarında görsel kültürde ilginç gerilimler barındıran temsiller olarak yerlerini alırlar. Ölüm imgesinin donuk karedeki masum görüntüsü birdenbire yerini vahşetin seyirlik gösterisine bırakır.

Şu halde, vahşet duygusunu ölü bedenin pervasız teşhiri üzerinden kurgulayan gazetecilik standardı üzerine de bir iki şey söylemek gerekmektedir. Özellikle de bu yaygın eğilimin vasati etiği üzerine... Öncelikle, söz konusu etiği haberin ekonomi politiğini dikkate almadan düşünmek olanaksızdır. Çünkü ölüm, reytingi yüksek bir metadır ve bunun medya endüstrisi tarafından keşfedilmesiyle birlikte, artık onun kutsallığından da söz edilemez. Dahası, Mestrovic'in deyimiyle, "duyguötesi toplum"da ölüm de artık iyiden iyiye "MacDonaldlaşmış", "ölü bedenin çağdaş defni bir bütün olarak makine kültürünün parçası haline gelmiştir" (1999, s. 249). Ölümün anlamının demistifiye edilerek herhangi maddi bir metanın tüketimiyle aynı duyarlıkta tüketilmesi, Mestrovic'e göre, çağdaş ölüm ritüelinin "katarsisi inkâr etmesi" ile ilgilidir. Bu ritüelde son söz hayatın olmadığı gibi ölümün de değildir. Yaşanan şey, bir dizi seremoniyle gizlenerek üstü örtülmeye çalışılan büyüdür. Bu yüzden de duygusal katarsis ne II. Dünya 
Savaşı'nda, ne Bosna Savaşı'nda, ne de günümüzün halen devam etmekte olan Suriye iç Savaşı'nda vuku bulmamaktadır artık. Aksine, ölümün tecelli edişiyle birlikte hissedilen tek şey kocaman bir boșluktur sadece. Bauman'ın da dediği gibi, "Ölümün dehşetini tam yaşamın merkezine getiren şey de bu boşluğun yeniden açılmasıdır" (2012, s. 66). Boşluğu dolduracak olan, hayatta kalan başkalarının ölümü gözlemleyen sesleridir. Öyleyse sorumluluk ölenlerde değil, ölenlerin ardından söz alıp konuşacak olan bu kişilerdedir. Zira Bauman'ın da belirttiği gibi, "Ölmek üzere olan kişiye yalnızca hayatta kalanların dilini sunabiliriz" (2012, s. 162). Ne var ki, hayatta kalanların dili dolaysız bir dil değil, temel niteliğini ölen kişinin acısına uzaklığından alan "aracı" bir dildir: "Bu dil, ölüm olgusunu ancak araçlaştııımış yaşamın bütün öteki öğelerini barındırdığı gibi barındırabilir; bir uygulama, bildirilmiş, hedeflenmiş ve üzerine odaklanmış bir çaba nesnesi olarak" (Bauman, 2012, s. 162). Bir nesne olarak ölüm ve ölü bedenin betimlenişi, şu halde öznel niyetlerin olası saptırıcı etkilerini de içinde barındırır.

Konuyu ölü bedenlerin mahremiyetinin iğdiş edilmesi bağlamında düşündüğümüzde, söz konusu iğdiş edici saptırmanın düzeyi daha da içler acısıdır. Hele de farklı ideolojik perspektiflerden tarif ediliyorlarsa... Sözgelimi “ölümlerin 'insanlaştırılması' (şehit cenazeleri) veya 'insandışılaştırılması' (gerilla cenazeleri) ile kurbanlar 'bizden' ve 'öteki' olarak sınıflandııılıklarında" (İnceoğlu ve Çoban, 2014, s. 148), yaşanan şey tam da budur. Böylelikle, "hangi ölüm için üzüleceğimiz, hangi ölümü meşru kılacağımız medyatik olanla dikte edilir" (Inceoğlu ve Çoban, 2014, s. 148). Bu, hayati önemde bir sorundur, zira farklı hayat tarzları üzerinde olduğu kadar "öteki"leştirilmiş kimliklerin ölümleri üzerinde de uzlaşmaz karşıtlıklar üretir. Deyim yerindeyse, ölümün evrenselliği nosyonuna ve "büyük eşitleyici" olma işlevine gölge düşürür. Bu uğursuz ayrıştırmada, ölen kişilere yakınlığın/yanlıığın veya uzaklığın/karşıtlığın belirleyici kriterler olarak işlev gördüğü bir durum söz konusudur. Başka bir deyişle, acıya doğrudan (zorlayıcı) veya dolaylı (taşıyıcı) tanıklığın neden olduğu bir algılama farklılığı. Bu farklılık ise, beraberinde daha başka çatışmaları ve gerilimleri getirir. Inceoğlu ve Çoban'ın da deyişleriyle; "tanık metnin kurgulanışındaki yanlıık ve çarpıtma toplumsal hafızanın çarpık oluşmasına neden olur ve biz-öteki karşıtlığını keskinleştirir" (2014, s. 150). Biz-onlar karşıtlığı böylece ölenler üzerinde de hükmünü icra etmeyi sürdürür.

Elbette konunun bir de ölü bedenlerin mahrem görüntülerinin yanlı ve çarpık sunuluşuna dair can alııı boyutları vardır. Nazmiye Kete'nin, mahremiyet olgusunu medya-yoksulluk/ölüm diyalektiği ekseninde irdelediği çalışması (2011, s. 61-83), "birey-toplum ilişkisinin karmaşık ve sonu gelmeyen çelişkilerini ezilenlerin mahremiyeti ve ölümü üzerinden ele almaya" odaklanır. Kete, çalışmasında, bir yandan da mahreme yönelik hiçbir özgürlüğü olmayan çevrelerin toplumsal ve sınıfsal "yaralarını" patolojik bir iletişim biçiminin içinden kavrarken; diğer yandan, mahrem olanın en dip sularına ve hayatın bugüne dek henüz mahrem olarak adlandııımamış, keşfedilmemiş ve dile getirilmemiş olan 
ara yüzeylerine ilişkin duyulmadık hikâyeler anlatır. Kete, iddiasını daha da ileriye götürüp şöyle yazar: "Yoksulların mahremiyeti yoktur!" (2011, s. 70). Ölenler, yoksul kişiler olduklarında, ölünün cansız bedeninin bile mahremiyeti hiçe sayılır. Çünkü onların yaşamları kadar ölümleri de sınıfsal açıdan değerlendirilir. Tıpkı Suriye iç Savaşı'nda can verenlerin, her gece hasarlı botlar üzerinde hayatta kalma mücadelesi veren mültecilerin veya diğer yoksul çoğunluğun uluslararası medyada haberleştirilmelerinde olduğu gibi. Öyleyse "ölüm de insanlar arasındaki eşitsizliğin göstergelerinden biri olarak ele alınmalıdı" (Kete, 2011, s. 74). Nurdan Gürbilek ise, Yabancının Ölümü adlı denemesinde, ölümün medyadaki sorunlu temsilinden çıkarılabilecek anlamları konu edinir. Gürbilek'in temelde vurguladığı şey, "bütün vahşet haberleriyle ve müşterisi haline getirildiğimiz ceset düşkünlüğüyle birlikte, ölüme bakışımızın gözle görülebilecek ölçüde değişmiş olmasıdır" (Gürbilek, 2001, s. 26-27). Gürbilek'e göre, bundan böyle ölümden söz edişimizin kamusal dili olumsuz biçimde tamamen değişecektir. Çünkü şaşaalı biçimde gösterisi sunulan ölüm imgeleri, ölüm haberlerinin tüketimini en cazibeli hale getiren kanlı görüntülerdir ve temelde bu biçimiyle tüketilen haberler, sadece ölüme karşı duyarsızlaşmayı değil, aynı zamanda başkalarının ölümünden duyduğumuz marazi heyecanı da gözler önüne serer. Zira ölenin yaşayan kişilerin zihninde bıraktığı duygu bir tatmin ve rahatlama duygusudur. Nitekim yazar Elias Canetti de gayet manidar biçimde hayatta kalma anının aynı zamanda "iktidar anı" olduğunu söylemektedir. Canetti'ye göre, ölümün görüntüsü karşısında duyulan dehşet, ölen bir başkası olduğunda tatmine dönüşmektedir (2006, s. 229). Ölümün başkasının rahatlamasına yönelik bir gösteri olarak sunulması, ölümün pornografisine ilişkin yakıcı bir dildir ve bu dilin tecimsel açıdan uyandırdığı ilgi, deyim yerindeyse, medya etiğinin de çöküş anını simgeler. Özellikle madun konumundaki (yoksul, işçi, düşük statülü kişiler, eşcinseller, politik, etnik, dinsel azınlık üyeleri, vb.) kişilerin ölümü öylesine mutat ve çekicidir ki, adeta medyatik ölüm salgının "patient zero"sunu oluşturur. Dahası, ölümü en çok da onlarda görmeye alışığızdır. Ölüm, öteki'nin, yoksulun, madunun, söylem düşkünü kimselerin ölümüdür her şeyden önce. Bu anlamda öteki'nin ölümü, ölümün ötekiliğidir. Sıradanlaştırılan, medyatize edilen, gözden düşürülen ölüm de bu tür çevrelerin ölümüdür esas olarak. Bu yaygın tercih, ölüme karşı belli bir farkındalık yaratmaktan veya anımsamayı dürtmekten ziyade unutmayı kışkırtır. Bu tür ölüm biçimleri, televizyon ekranlarında yoğun bir dramaturji içinde sunulduğunda, temsil edilen ölüm olayları ve ölüm anı görüntüleri izleyiciyi bizatihi ölüm gerçeğine karşı yabancılaştırıcı bir işlev görür. Çünkü "ölüme dair imgeler ve görüntüler aşırıdır, fazladır ve bu nicel yoğunluğu ölüme gerçek dışı bir boyut kazandırır" (Tutal Cheviron, 2014, s. 55). Ölüm duygusu, ölüm görüntülerinin sık ve yoğun sunum tarzı nedeniyle umulan etkiyi uyandırmaz izleyicide. Dahası, "görüntü değeri yüksek, felaket, savaş ya da bombalı saldırı gibi olaylar; ortada cesetler olmadığında [dahi] binlerce kişinin dramı, yokluğu ve boşluğuyla gösterilir" (Tutal Cheviron, 2014, s. 55). Ölüm gerçeğine yabancılaşma, bu medyatik sunum biçiminin neden olduğu olumsuzlukların en büyügüdür. Zira acıdan, yıkımdan, felaketten çok, estetize edilmiş bir ölüm gösterisi "medya izleyicisini bireysel ölüme hazırlamaz. Ölüm temsillerinde ölümün parodisi yapılır" (Tutal Cheviron, 
2014, s. 56). Nilgün Tutal Cheviron, ölümün medyatikleşmesi sorununu analiz ederken, iki noktanın daha altını çizer: Ölüm temsillerinin izleyiciyi sahte bir şekilde öznenin mahremiyetiyle bağlantılandırması ve medyatik bir ritüel olarak sunulan ölümle seyirci arasına konulan duygusal mesafe $(2014$, s. 57). Özellikle bu sonuncusu, seyircinin ölümün korkunç gerçekliğine ya da ölen kişinin yokluğuna tahammül edebilmesini sağlar. Bunun anlamı ise, ölüme ve ölüm duygusuna karşı duyarsızlaşma, kayıtsız kalma, ilgisizleşme, hissizleşme, vb.dir. Ölüm imgelerinin medyatik enflasyonu ise, olsa olsa en başta ölümün değerini azaltır. Çünkü ölüm, gerçekte ender yaşanan ve vuku bulduğu anda da hayatı değerli kılan bir olgudur. Ölüm, yaşamda sınırlı tasarruf edilebilen bir şey olduğu içindir ki, aslında çok değerlidir (Schmid, 2015, s. 86). Denilebilir ki, ölüm anının değersizleştirilmesi, onun seyirlik bir izlenceye dönüştürülmesiyle gerçekleşmiştir.

Bu seyirlik izlencenin en yıkıcı biçimi ise, kuşkusuz savaştır. Görüntüsüz savaş olamayacağı gibi, algıda bir çatışma içermeyen görüntü de yoktur. Bunun anlamı ise şudur: Görüntü de en az savaş kadar yıkıcı ve etkilidir. Nitekim Sontag'ın dediği gibi, "bir nesneyi 'çeken' (shooting) kamera ile bir insana 'ateş eden' (shooting) silah arasında önüne geçilmez bir özdeşlik şekillenmektedir" (2004, s. 67). Kameranın objektifini bir silah namlusu olarak betimlemek fazla abartılı bulunabilir. Ne var ki, Sontag'ın savaşmak ile fotoğraf çekmek arasında kurduğu korelasyon, ortaya koyduğu sonuçlar itibariyle hiç de kuşku götürür bir iddia değildir. Bazen can yakıcı bir görüntü savaşa yol açabilir, bazense görüntünün kendisi başı başına bir savaş ve mücadele silahıdır. Nihayetinde "silah ile fotoğraf makinesi aynı aklın ürünüdür" (Sontag, 2004, s. 67). Özellikle de Doğulu, Uzakdoğulu, Afrikalı, Ortadoğulu veya Asyalılara ait cepheden görüntülenmiş, mahremiyetleri hiçe sayılmış veya feci biçimde sakatlanıp yaralanmış bedenlerin (Sontag, 2004, s. 73), öteki'ne bakışa, dışlanmaya, aşağılanmaya veya tarafgirliğe ilişkin güçlü referans çerçeveleri oluşturduğu düşünülürse, söz konusu savaşın etkileri dezavantajlı kesimler açısından daha da yıkıcı hale gelir. Şu halde fotoğrafın çerçevelediği sorunlu anlamı belirleyen tercih önemlidir ve bu örseleyici dili görsel yoldan inşa eden vizyon araçlarının (fotoğraf makinesi, video kamera, vb.) semiyotiğine ilişkin de bir şeyler söylemelidir.

\section{"Sapkın Vizör" ya da Ölüm Gösterisinin Seyirlik Araçları}

Fransız göstergebilimci Roland Barthes, Camera Lucida isimli yapıtında, fotoğraf makinesinin icadıyla birlikte, 19. yüzyılın başlarında ortaya çıkan yeni bir görsel algılama paradigmasından söz eder. Barthes, fotoğraf makinelerini "görmenin saatleri" olarak tanımlar (1992, s. 24). Bu anlamda, görmenin saatleri, düşünmenin uyukladığı ya da askıya alındığı süreğen bir molanın deneyimlendiği yerdir. Barthes'ın deyimiyle "bakışın ısrarı", zihnin etkin durumda olmadığı saatlerin bilinçdışı belgelerine ilişkin kanıtlar sunarken, her tür zihinsel aktiviteyi, koşulsuz mutlak olarak, boşluğun kendisine yeniden iade eder. Bu nedenle fotoğrafta "doğru an"ı bulmak, Barthes'a göre, sadece şimdi'yi geçmişten koparma işlevi görmez, aynı zamanda şimdi'yi "geçmiş gerçekliğin bir yayılışı 
olarak" yeniden kurar (1992, s. 95). Bu anlamda, fotoğraf, sonsuz şimdiye odaklı olarak iş görür, yani ölümsüzlüğe odaklı olarak... Barthes'a göre, özel yaşantı denilen şey, kişinin "aslında bir görüntü ya da bir nesne olmadığı o mekân ve zaman dilimi"nden başka bir şey değildir (1992, s. 24). Yani bir anlamda, ancak kişinin yaşamı görüntülenecek bir nesne olduğu zamanların dışında bir anlam kazanır ve "seyirlik" bir yaşam, bu şekliyle, özne olarak bireyin var olma deneyimine aracılık edemez. Çünkü kişisel deneyimin aktarılamazlığı, deneyimin metalaştırımasının önündeki en büyük engellerden birisidir. Oysa fotoğraf, özneyi donuk bir nesneye dönüştürerek metalaştırır ve içinde yer aldığı doğal süreçten ve bağlamdan koparır. Bu nedenle Barthes'a göre, fotoğrafta, en "acı verici olduğu anda bile, hiçbir şey, kederi yasa dönüştüremez" (1992, s. 97). Aynı şekilde, zamana belli bir bütünlük kazandıran süreklilik duygusu bozulmadan da an'ın hakikati kurulamaz. Bu yüzdendir ki, an içinde yapılandııımış bellek, "o an"ın dışını anımsamaz. Başka bir deyişle, sadece "olay"ı anımsayan, olayın öncesini anımsamaz. Barthes'ın da dediği gibi, "fotoğraf geçmişi anımsamaz (bir fotoğrafın Proust'çu yanı yoktur). [Bizde] yarattığı etki, (zamanla ve uzaklıkla) bozulmuş olanı yenilemesi değil, gördügüm(üz) gerçekliğin gerçekten de var olduğuna tanıklık etmesidir. (...) Ve bu, skandal yaratan bir etkidir" (1992, s. 89). Çünkü fotoğrafik bilgiye katılım, belli bir öznel deneyim gerektirmez, kişiyi salt olup biten karşısında dolaylı bir tanıklık düzleminde bırakır; ne var ki, aslolan böyle bir tanıklık durumu değildir; fotoğrafı çekenin ya da onu algılayan gözün olayı deneyimleme olanağının, bir başka deyişle, "katııı" olanağının olup olmamasıdır.

Özne, bu son konumundan dolayı, Sartori'nin deyimiyle, homo videns, yani "gören insan"dır. Bu anlamda görmek, algılamış olmanın ilk koşuludur. Sartori, Görmenin Iktidarı isimli yapıtında, böyle bir insanı geçerli kılan kültürün "bizi, anlamadan görmeye yönlendiren, görülebilenin anlaşılabilene üstün geldiği" (2006, s. 12) bir kültürün açmazlarına eğilir. Öte yandan, Sartori, görüntüye dayalı bilginin somut olaylara ve sorunlara ilişkin anlam üretme gücünü büsbütün yadsımamakla birlikte, bu tür bilgiye hayati bir rol de atfetmez. Bu konuda verdiği örnekler, somut olarak görüp algıladıklarımızın belli bir "fikir" vermediği gerçeğine değil, bu fikirleri geliştirebilme olanağının dar çerçevesine işaret eder. "Örneğin, işsizlik" diye yazar Sartori, "işsiz bir insanın görüntüsüyle; mutluluk, memnun bir yüz fotoğrafıyla; özgürlük hapishaneden çıkan bir kişi göstererek ifade edilir. Eşitlik sözcüğünü, iki bilardo topunu gösterip, 'işte aynı şeyler' diyerek ya da zekâ sözcügünü bir beyin göstererek açıklayabiliriz. Ancak bunlar, sadece söz konusu kavramların saptırılmış ifadeleridir. Bir işsizi göstermek, işsizliğin nedenlerini açıklayamayacağı gibi, bir çözüm önerisi de sunmaz" (2006, s. 34). Aynı durum, görsel iletişim araçlarının her türü için geçerlidir. Hepsi de kişiyi analitik-bilimsel bilme becerisinden sistematik biçimde yoksunlaştırma araçlarıdır. Sartori'yi izleyerek söylersek, "televizyon, görüntüleri üretirken kavramları siler ve böylece soyutlama yeteneğimizi ve onunla beraber tüm anlama edimimizi azaltır" (2006, s. 35). Sartori'nin "görüntülerden edinilen bilme" (2006, s. 38) diye adlandırdığı şey, bizi metalaşmış deneyim dünyasının başlangııına gönderir. 
Bu metalaşmış dünyanın görsel bilgi biçiminin ideolojik işleviyle birleştiği yerde ise, Debord'un duyumsal dünyanın egemenliğindeki gösteride "toplumun tahakküm altına alınması" (2006, s. 50) dediği durum beklemektedir bizi. Debord'un belirttiği gibi, "gösterinin görünür kıldığı hem var hem de yok olan dünya, yaşanmış her şey üzerinde hâkim olan metalar dünyasıdır" (2006, s. 50). Debord'un görüntüye dayalı bilgi birikiminin yoğunlaşmış gösterisi ile fiili toplumsal etkinlik arasında kurduğu diyalektik ilişki ise, gerçekliği algılamakla onun "üzerine düşünmek" arasındaki derin düşünsel çatlağı gözler önüne serer: "Gerçek olanı tersine çeviren gösteri" diye yazar Debord, "fiili olarak üretilmiştir. Aynı zamanda yaşanmış gerçeklik de gösterinin seyri tarafından maddi olarak istila edilmiştir ve gösteriyi benimseyerek gösteri düzenini kendine katar. Nesnel gerçeklik her iki tarafta da mevcuttur (...) Gerçeklik, gösteri içinde birdenbire belirir; gösteri gerçektir. Bu karşılıklı yabancılaşma, var olan toplumun özü ve dayanağıdır" (2006, s. 38). Gösteri, kendi hakikatine yabancılaşmış toplumun tarihsel anına tanıklık eder ya da başka bir deyişle, gerçekliğin zamansal kullanımından başka bir şey değildir. Debord'un gösteri toplumu hakkında dile getirdiği görüşler, yaşanan anları tüm "canlı"lığıyla içine alan bu tarihsel anın tanıklığıyla doludur. Şayet görüntünün gerçekliği, gerçekliğin görünmeye değer bütün bölümlerini açığa vurmayı iddia ediyorsa, o halde "görünen şey iyidir, iyi olan şey görünür" (Debord, 2006, s. 39) diyen olumluluk, yabancılaşmış medyatik toplumun sahiplenebileceği tek olumluluk biçimidir. Bu çıkarım, doğal olarak, yaşamın iyiyi de kötüyü de kendi içinde harmanlamış bütünlüğünün değil, şimdiki an'ın görünür gerçekliğinin yüceltilmesiyle son bulur. Şimdiki an'ın görünür gerçekliği her zaman iyimser düşüncelere yataklık etmeyebilir. Sözgelimi trajik bir olay anında fotoğraflanmış ölü bedenlerin parçalanmış görüntülerinin sunduğu manzara, adeta objektiften yansıyan örselenmiş bir tablo gibidir. Bu fotoğraflara bakıp da acı duymamak, bu fotoğrafları görüp de irkilmemek, bu yıkıma, bu kıyıma yol açan şeyi ortadan kaldırmak için uğraş vermemek; Woolf'a göre, tüm bunlar ahlaktan ve vicdandan nasibini almamış bir canavarın vereceği tepkilerdir (Aktaran Sontag, 2004, s. 6-7).

Sontag, elem ve acı verici durumların görsel kayıtlarını tutan fotoğrafçılara şu tür ölümcül sorular yöneltir alttan alta: Fotoğraf bir olgu olarak savaşı mı yoksa insanların can çekiş̧en hallerini mi belgelemelidir? Ya bu içler acısı manzaralara tanıklık eden fotoğraflar? Bunların yayımlanması ne kadar etiktir? Ölü bedene ya da acı çeken birine duyulan saygı ve ölümün kutsallığı nerededir? Sadece "başkalarının acısına bakıp" geçmek midir fotoğrafçının yapacağı şey, yoksa bu acıyı paylaşmak mı? Sontag'ın bir dizi soruyla yokladığı sorunsalın gizli varsayımı şudur: Bir vahşetin uzaktan kaydını tutan görüntüler gerçekte kolaylıkla birbirine zıt tepkiler de uyandırabilir; bu bir barış çağrısı da olabilir, bir öç çığlığı da. Ancak bir savaş söz konusu olduğunda, fotoğraf tek bir dile sahiptir genellikle; acının dilidir bu (Sontag, 2004, s. 11-12). Acıya uzaktan veya ikinci elden yapılan bu tanıklığın savaş dışında da belli bir kuşatıcı gerçekliği olduğu muhakkaktır. Acıya dolaylı ve uzak tanıklığın oluşturduğu mesafenin izleyici duyarlığını köreltici yönü, kuşkusuz algı körelmesinin ve sonrasında ise vicdan körlügüne giden yolun 
yatağını döşeyen gelişmelerden birisidir. Şimdi bu algı ve vicdan körelmesine giden yolu döşeyen taşlara somut olarak göz atalım.

\section{Ölümün ve Ölü Bedenin Medyatik Sunumu}

"Aynı 'sokağın' insanı değilsek, çok önceden terk etmiş oluyoruz birbirimizi."

Betül Dünder, Varlık, Haziran 2015, s. 6

Ölümün egemen medya sunum biçimlerine yansıyan gölgesi cesetlerin fütursuz teşhirine fazladan bir karanlık eklemektedir. Dahası, sosyal medyada sansürsüz ve denetimsiz biçimde yayımlanan kadın, erkek ve çocuk cesetlerinin geçmiş yıllara oranla trajik sözcüğünü bile geride bırakacak ölçüde dehşetengiz temsillerine tanıklık etmekteyiz. Bu temsil biçimlerinde ölümün ve ölü bedenin adeta incelikli bir Hollywood prodüksiyonu gibi işlem gördüğü bir durum söz konusudur.

Fotoğraf 1. Suriye İç Savaşı'ndan Bir Kare, Foto: Jerome Sessini / 20 Ekim 2012 (http://levracdupasseur.tumblr.com, 12.02.2016)

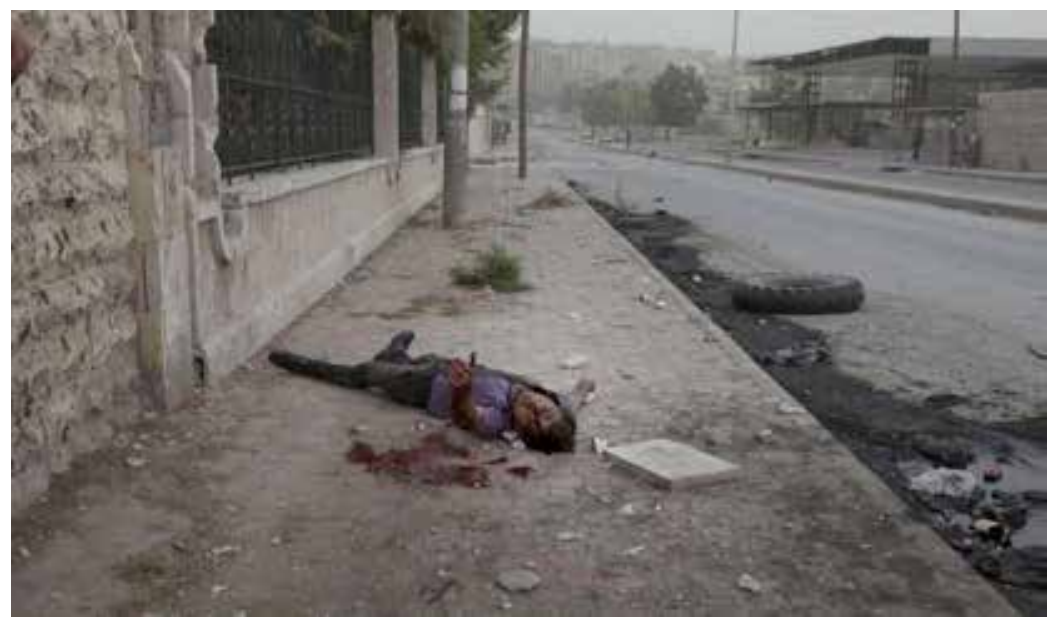

Fotoğraf 1'de, terk edildiği izlenimi veren metruk bir mahalde boylu boyunca yerde uzanmış yatan bir insan görülmektedir. Yerdekinin ölümünün gözlerden uzak bir mıntıkayla birleşen görüntüsü patetik bir etkiye sahiptir. Fotoğrafı çeken Jerome Sessini, beyhude biçimde yalvarırcasına elini kendisine doğru uzatmış izlenimi veren yerdekine takındığı kayıtsız tavırla adeta ona sırtını dönmüş gibidir. Asıl yıkıcı olan da budur fotoğrafta; insanlığa ilişkin onur yarası veya vurgun tam da bu umursamaz edada somutlaşmaktadır. Yüzün neredeyse hiç gizlenmeden, ters bir açıyla cepheden sunulan görüntüsü, insani varoluşun belirgin biçimde hissedildiği, aura'sı en yoğun olan bölgeyi, yani "yüz"ü adeta ihbar etmektedir. Insanın kimliğini tüm çıplaklığıyla ele veren en kişisel anlamların yüklü olduğu 
alan, böylece biricik niteliğinin ona bahşettiği derinlikten de arındırımaktadır. Yüze sataşan objektif, aynı anda iki şeye birden; hem hayata hem de ölümün kutsiyetine her ikisini de geçersiz kılmak suretiyle sataşmakta gibidir. Mizansenin teatralliği ise, satışı garantileyen ve etkisi "hesaplanmış" bir drama ürünüdür adeta. Ölü bedenin etrafındaki irili ufaklı nesnelere bakıldığında, burasının gözden çıkarılmış bir çöplük izlenimi veren niteliğinden de hareketle söylenirse, adam "atıl bir nesne" konumundadır. Iskartaya çıkarılmış bir hayat temsilidir bu. Ölümün önemsizleştirilmesinin şiddetle hissedildiği anlamsal çağrışımın doruk noktası da burasıdır. Nesnel uzama bitiştirilen ölüm insandışılaştırılmıştır. Söz konusu uzam, her türlü bilinçli etkinliğin sonudur. Hiçbir surette duygusal bir katarsise izin vermeyen nesnel bir soyutlamadır burada bedenin maruz bırakıldığı durum... Öte yandan aynı nesnel temsil, ölümün şiddetin en hoyrat biçimiyle üstü örtülmüş gizemini, gösterileninden yoksun bir gösteren olarak, kanlı malzeme sunan görüntülerden daha fazla sakatlamaktadır. Çünkü görüntü, ima ettiği uzak tanıklık bakımından zengin çağrışımlar içermektedir. Tam da Silverman'ın "uzaktaki özdeşlik" (2006, s. 32) dediği şeydir bu. Fotoğraflayan da fotoğrafı çekilen de aynı uzak özdeşlik yüzünden birbirlerine yabancıdırlar. Kuşkusuz, bu görüntünün bakanda dehşet duygusu uyandırdığı şeylerden birisi de, boş sokağın verdiği ürpertinin ölüme yüklediği fazladan anlamdır. Ölümün, vuku buluşuyla birlikte hayata eklediği "artık duygu", tam da sokağın boşluğunun içerdiği ıssızığın ürpertisinde cisimleşir. Sokağın boşluğu, deyim yerindeyse, "postmortem" bir gösteren olarak yerdeki bedenin içinin boşluğudur. Bedenin içi tuhaf sesler, uğultularla doludur. Issızlığın beden etrafında ördüğü duyarlığın özü de budur; bir uğultudan ibarettir. Ölüm, artık bu andan başlayarak ideal ya da yüce bir imge değildir; zira "özne, ideal imgeye yaklaşmanın olanaksızlığını bedensel çözülme fantezisi aracılığıyla anımsar" (Silverman, 2006, s. 39). Bedensel çözülme, sadece ölümü ideal anlamından yoksun bırakmaz, aynı zamanda kişisel mahremiyet alanının sınırlarını da cömertçe dışa açar. Ve tüm bu olumsuz çağrışımlar, fotoğraf makinesinin vizöründen bakan gözün kendi öznellik kaygısını özdeşlik ilkesi bakımından yerdekiyle aynı hizada tutamamasının bir sonucudur. 
Fotoğraf 2. Suriye İç Savaşı'ndan Bir Kare, Foto: Manu Brabo /3 Ekim 2012 (http://www.fotoevidence.com/manu-brabo, 10.02.2016)

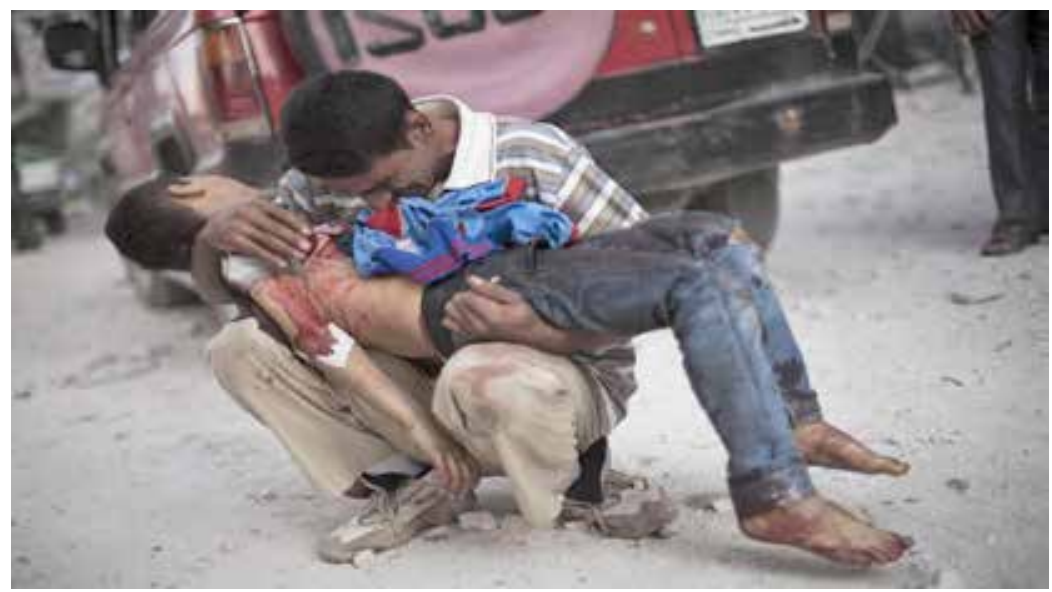

Fotoğraf 2'deki Manu Brabo imzalı görselin kulağa fısıldadığı ilk düşünce, dramın semantik yoğunluğunun yoksullukla daha da katmerlendiği gerçeğidir. Çocuğun çıplak ayakları, dizleri yırtık pantolonu, adamın perişan görüntüsü, vb. Bir babanın hastanede henüz can vermiş çocuğunu gözyaşları içinde ve belirgin bir acziyet içinde kucağına alarak sergilediği çöküş anı, yere, toprak seviyesine doğru çömelmesiyle verilmiştir ve hiç kuşkusuz bu görüntüsel gösterge sinematografik değerini temsil ettiği olayın kurgusal çerçevesine borçludur. Genel anlamda, fotoğrafın izleyicinin zihninde ürettiği temel etki ya da ektiği anlam, doğruluğu kuşku götürmez epistemolojik bir hâkimiyet duygusudur: Savaşın onay gördüğü bir dünyanın yol açtığı mutlak umutsuzluğun ve gelecekteki güven ilişkilerinin tükenişinin düşünsel olarak teyit edildiği bir andır bu. Nitekim yetişkin birisinin değil de, özellikle bir çocuğun ölümü potansiyel insanlık imgesine ilişkin simgesel bir imhadır. Fotoğraf, bu anlamıyla, "gözün aynı anda hem zaferi hem de mezarıdır" (Silverman, 2006, s. 191). Zaferidir, çünkü Barthes'ın deyimiyle, en dokunaklı anı; izleyenin zihninde derin izler bırakan, delip geçen bir ilgiyi, yani "punctum" anını yakalamıştır. Gözün mezarıdır, çünkü tüm zamanların en karanlık dürtüsünü, ölümün yakıcı gerçekliğini belgelemektedir. Üstelik fotoğrafın arkasına aldığı görüntü, uygarlığın metalik soğukluğunun somutlaşmış biçimi olan (bir tür "soğuk yakınlık" olan) kamyonet figüründen başka bir şey değildir ve bu insan etinin hassas ve yumuşak dokuları, ona eşlik eden endüstriyel çeliğin ruhsuz görüntüsüyle daha da kırılgan hale gelir. Kucaktaki çocuğun bel ve karın bölgesini açıkta bırakan çıplaklığın ölü bedeni kodlayışı ise, adeta bir et yığınından farksızdır. Öte yandan, masum bedensel mahremiyetin bu kanlı gösterisi, anlamsal açıdan keskin bir zıtlık içinde, yetişkinlerin suçlu ve günahkâr dünyalarının yıkıcılığını daha da belirgin hale getirir. Manu Brabo bu zıtığın açıkça farkında olmalıdır ki, tanıklık ettiği gerçekliğin örseleyici boyutunu, bir tür nedamet getirmeyi andıran babanın 
ağlayışıyla bütünleştirmiştir. Acının evrensel bir mitolojisini kurgulayan bu kare, ezilen yoksul sınıfın ölümü üzerinden tescillenmiş bir eşitsizliğe işaret etmesi açısından da önemlidir. Brabo'nun fotoğrafı, yukarıda sözünü ettiğimiz ölümyoksulluk-medya ilişkisinin de verili anlamlarını açığa vuran somut bir vesikadır bu açıdan. Çocuğunun ölü bedeni üzerine kapanmış acılı babanın matemiyle tahkim ettiği çaresizlik, ölmüş ya da acı çeken bedenlere duyulan marazi ilgiyi bertaraf etmeye kesinlikle yetmemektedir. Nitekim deklanşöre basan parmak, soğukkanlı bir kesmeyle, sadece ayaklarından birini çerçeve içine dâhil etme gereği duyduğu gizli bir tanık vasıtasıyla, sahneye dış algısal egonun uzak özdeşliğini eklemiştir... Bu açıdan, Sontag'ın dediği gibi, fotoğraf karesinin odağındaki kişiler dışında "hepimiz -kendimize yüklediğimiz anlam ne olursa olsun- birer dikizciyiz" (2004, s. 41).

Fotoğraf 3. Suriye İç Savaşı'ndan Bir Kare (http://www.aksiyon.com.tr, 09.02.2016)

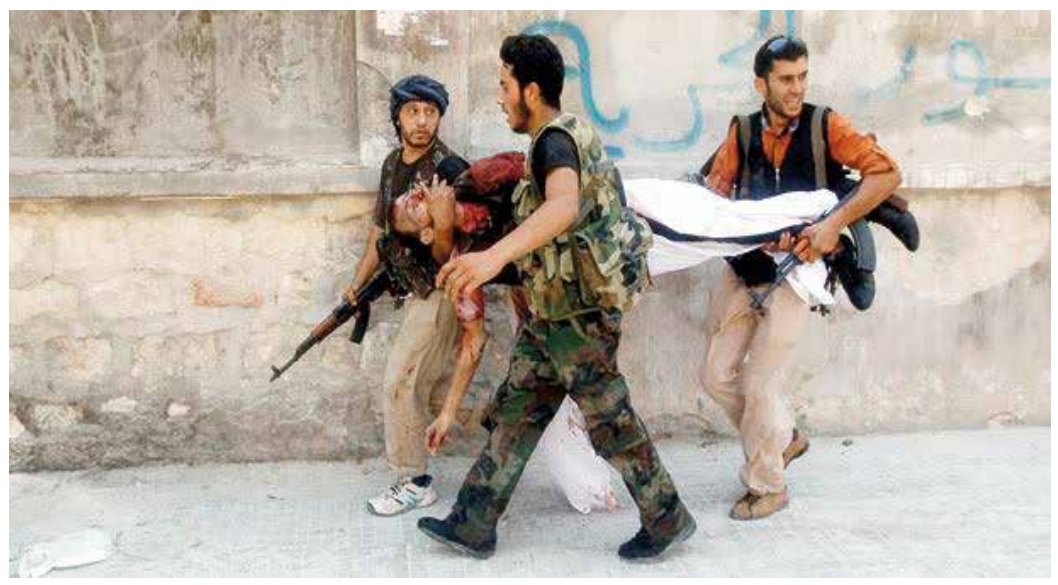

Yukarıdaki görselde (Fotoğraf 3 ) ise, üç adam ellerinde yaralı olduğu anlaşılan bir bedeni taşımaktadırlar. Üstelik üçü de silahlı kişilerdir. "Kurtarıcıların" silahlı kişiler oluşları çerçeveye ayrıca ironik bir hava katmaktadır. Fotoğrafı çeken kişinin üstü beyaz bir çarşafla örtülmüş ayakları değil de, kanlar içinde aşağı doğru sarkan kolları ve başı açıkta bırakan bir çerçevede karar kılmış olması şiddetin vurgulu sunuluşu açısından oldukça manidardır. Yaralının sağ tarafındaki kişi sol kolunu duygusuzca adamın başının arkasından yüzüne doğru bastırmış, arkada bacakları tutanın başında ise bir güneş gözlüğü var. Sanki insan değil de bir eşya taşır konumda sunulmuş her ikisi de. O kadar sıradan bir iş yapıyor tavrı takınmışlar ki, adamların üçü de taşıdıkları kişiye bakmıyorlar bile... Tıpkı kendiliğinden işleyen bir makine düzeneği gibi, dokunsal bir temasın tuhaf uzaklığını yaşıyorlar. Mekâna baktığımızda ise, duvarda Arapça yazıımış bir yazı var. Savaş ve mücadelenin duvarlara kazınmış hıncı, ölümün anlamından 
daha baskın bir vahşetin ebedi sürekliliğine işaret etmekte gibi adeta. Retoriğin gerçekliğe egemenliği demeli belki de. İkinci olarak, eğer duvar diplerinin tekinsiz ilişkiler ve olaylardan izler barındırdığı varsayımı doğruysa, referans karemizde yer alan, ölü mü yoksa yaralı mı olduğu pek de anlaşılmayan adamın akıbetine ilişkin çok da umut verici şeyler söyleyememekte bize. Üstelik taş duvarın oluşturduğu fon, bakanda bir tür kıstırımışıı hissi uyandırmakta. Adamı taşımak için sedye yok, zira egzotik ve mümkünse "geri" coğrafyalardan mutlaka yürek paralayan, perişan, bakımsız manzaralar içermeli kare. Eğer bu olay Fransa'da, ABD'de ya da bir başka gelişmiş ülkede yaşanmış olsaydı, yine de böyle kan revan içinde görüntüler sunulur muydu? Kuşkusuz ki hayır... Falkland çatışmasında ve Körfez Savaşı'nda, İngiliz ve Amerikalıların savaşla ilgili haberlerde bazı ifade kullanımlarını yasaklamaları ("korkunç bir şekilde yanmış", "ölen siviller" yerine "kısmi zarar", "halk" yerine "yumuşak hedefler", vb.) ve torba içinde taşınan ceset görüntülerinin yayımlanmaması zorunluluğu getirmeleri, vb. anımsanacak olursa (Williams, 1998, s. 194-195), bu konuda ne tür incelikli önlemlerin alınmış olduğu kolayca anlaşılabilir. Tüm bu önlemlerle yapılmaya çalışılan, gelişmiş batıı ülkelerin ölümü kendilerinden uzak tutma, ölümle aralarına bir mesafe koyma düşünceleridir. Ölüm gerçeğine yabancılaşma da burada başlar. Çünkü Sontag'ın dediği gibi, "uzaktaki acıları gösteren fotoğraflar" daha önemli bir başka işlev görürler: "Insanlar kendilerine yakın olan acılara pek bakamazlar" (2004, s. 99). Tanıklık edilen acı hep başkalarının, uzaktakinin, öteki'nin hayatıdır.

Fotoğraf 4. Suriye İç Savaşı'ndan Bir Kare, Foto: Khaled Khatib (http://www.ledevoir.com, 08.02.2016)

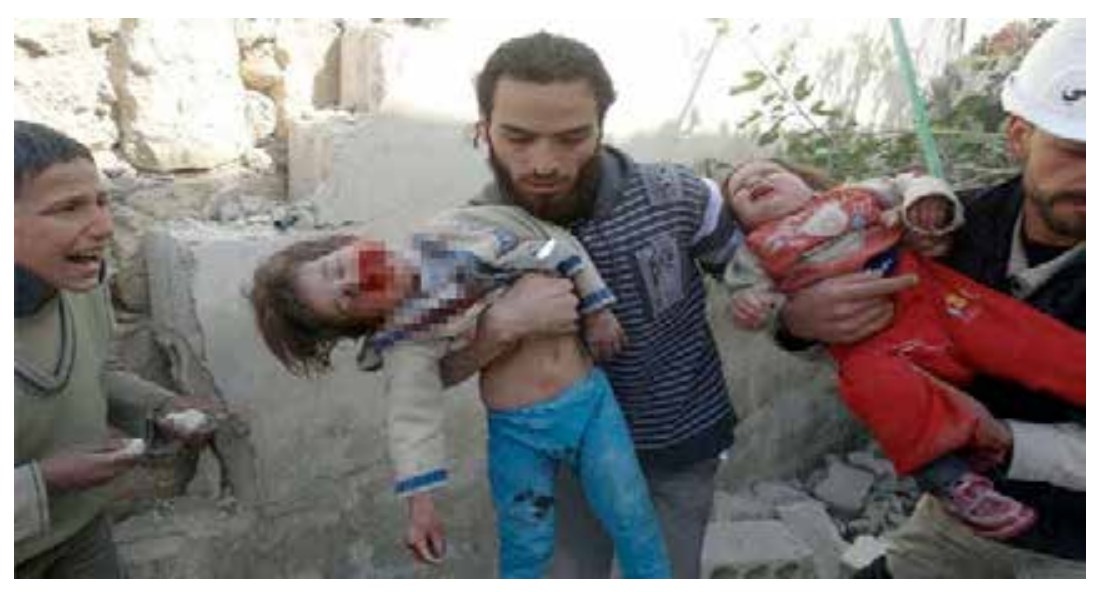

Medyada çocukların temsil edilişi ve çocuk hakları ilişkisi dikkate alındığında, genellikle yaygın gözlenen eğilimlerden biri, Tosun'un da belirttiği gibi, "çocukların haklarının değil, sistemin işleyişinin korunmasıdı" (2007, s. 185). Fotoğraf 4'te de benzeri bir eğilim göze çarpmaktadır. Burada da sansasyonel ve ajite edici görüntülerin ticari ederi, toplumsal acının bir başka boyutuna tahvil edilmiştir: 
Çocuklara. Burada dehşet duygusunu uyandıran temel etki, "ölümü bir çocukta görmenin yıkıcılığı"dır. Özellikle savaş, yoksulluk, açlık, göç vb. durumlarda çocukların belli haklara sahip bireyler olarak değil de, "acınası", "uzak durulası", aciz varlıklar olarak (Tosun, 2007, s. 191) temsil edilmesi, yaygın gazetecilik etiği ihlallerindendir. Eğer fotoğrafta çocuk unsuru varsa daha da özenli olmak gerektiğini vaz eden gazetecilik düsturunun, adeta kasıtlı biçimde hiçe sayıldığı bir karedir bu. Dahası, sağ taraftaki kız çocuğunun durumun vahametini daha da dayanılmaz kılarcasına ağlar halde görüntülenmesi acının pornografisine dair önemli ipuçları sunmaktadır. Çığlığı atan çocuk, ileriki yaşlarında bu fotoğrafı her gördügünde muhtemelen o gün yaşadığı acıyı yeniden anımsayacaktır. Soldaki küçük kız çocuğunun ağzı kanlar içindeki görüntüsü (ölmüş olma intimali yüksektir) fotoğrafta mozaiklendiği halde, göbek kısmının açıkta bırakıldığı dikkati çekmektedir. Yalnızca kanlı ağız bölgesi değil, küçük kızın yüzünün tamamının mozaiklenmesi gerekmektedir hâlbuki. Ayrıca bu mahremiyet ihlalinin yanı sıra, aynı karede ciddi biçimde gerçekliğin deformasyonu söz konusudur. Fotoğrafın ekli olduğu haber metninde "bölgede hastane ve ilaç sıkıntısının olduğu", öyle ki, "ameliyat için anestezi yapmanın mümkün olmadığı noktaya gelindiği" ve "insanların demir çubuklarla dövülüp bayıltıldıktan sonra ameliyata alındığı" ifadeleri yer almaktadır (http://dunya.milliyet.com.tr, 15.06.2014). Hâlbuki yukarıdaki fotoğrafın altına böyle bir haber metni yazmak, adamın kucağındaki çocuklar sanki demir çubuklarla dövülmüşler gibi bir algı yarattığı için gerçekliği tamamen çarpıtmaktadır. Çünkü bu çocuklar gerçekte bir hava saldırısı sonrası enkaz haline gelmiş olan bir binadan çıkarılmışlardır.

Fotoğraf 5. Suriye İç Savaşı'ndan Bir Kare,

Foto: Narciso Contreras /23 Ekim 2012 (www.ntv.com.tr, 10.02.2016)

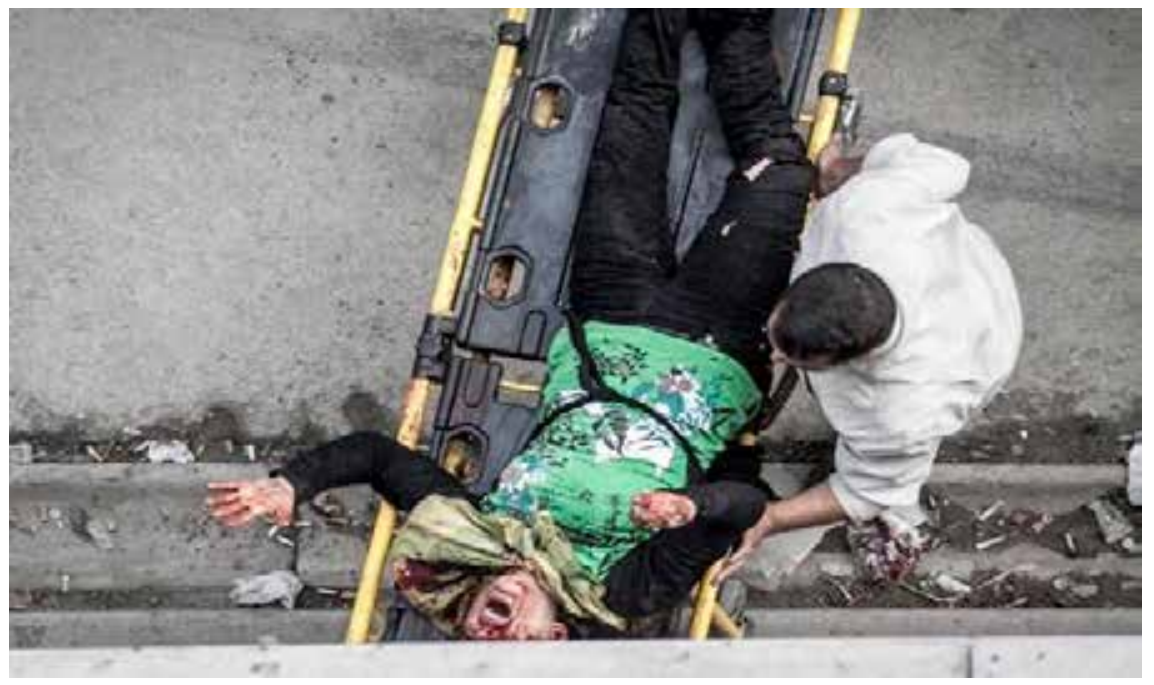


Fotoğraf 5'te foto muhabiri Narciso Contreras bizleri acılar içinde kıvranan bir yetişkin bedeninin yukarıdan üst açıyla çekilmiş görüntüsüne tanıklık etmeye davet etmektedir. Acıya bu denli dolaysız ve deyim yerindeyse, sinematografik açıdan takıntılı bir çekim ölçeğiyle tanıklık etmekle izleyiciden talep edilen dikkatten umulan yarar ne olabilir? Şayet incelikli bir seyir zevki sunmak değilse, kuşkusuz şiddetin ve duyulan acının dehşetini en tepe noktasına vardırarak izleyiciyi doyuma eriştirmeyi hedeflemiş olmalı... Fotoğrafta, cinsiyeti tam olarak belli olmamakla birlikte, yaralı, kollarını iki yana açmış avazı çıktığınca bağırmaktadır. Objektifini Halep'in Hananu bölgesinde bir ekmek fırını önünde kuyrukta bekleyen insanları vuran bombanın neden olduğu faciaya çeviren Contreras, "bir kamyonetin içine konularak hastaneye taşınan yaralıların yanık koktuğunu" belirttiğine göre (www.ntv.com.tr, 10.02.2016), gazetecilik etik tavrını, yapıtını olayların arka plan bilgilerini de ekleyerek daha da zenginleştirmekten yana kullandığı söylenebilir. Yaralının kanlar içindeki açık ağzı vahşetin ilk elden inbar edilişi gibidir ve eğer acıya ve ölüme sadece onu deneyimleyenlerin tanıklık edebileceği varsayımı doğruysa (Améry, 2015), sedyedeki yaralının, maruz bırakıldığı dehşetin ilk elden doğrulamasını yaptığı söylenebilir. Dehşet duygusunu temsili olarak aktaranda değil de onu bizzat yaşayanda görmenin etkisi kuşkusuz daha travmatiktir. Yaralının yüzünün kadraja özellikle (baş aşağı bile olsa) sığdırıması ise, yegâne aura'ya sahip olduğu söylenen insan yüzünün büyü bozumuna aracılık etmektedir büyük ölçüde. Sedyenin yerdeki yatay su arkına, onu çaprazlama kesecek biçimde -dikey olarak- yerleştirilmesi ise, algıda uyumu bozan göstergelerden birisidir. Çünkü dikey ve yatay çizgisel hatlar, açık biçimde bir çıkmaz duygusunu imlemektedir. Karede, bakan gözü duyusal bir karmaşaya sürükleyen -dolayısıyla terslik ve tekinsizlik duygusu üreten- bir diğer ayrıntı, beyaz önlüklü adamın durduğu sağ tarafta oluşan fazladan eğimin varlığıdır ki, bu görüntü içerdiği yan anlam bakımından ortamdaki tehlikenin varlığına işaret etmektedir. Peki sedyenin solunda onunla simetrik bir görüntü oluşturacak ikinci bir sağlık görevlisinin bulunmayışını ayrıca nasıl yorumlamalıdır? Imkânların yokluğuna mı yormalıdır bu durumu, yoksa sağlık hizmetlerinin yetersizliğine mi? İhmal edilmişlik hissinin yoğunluğu olarak mı okumalıdır, yoksa yaralının süregiden bahtsızlığının mutat bir göstergesi olarak mı? Hangisi olursa olsun, Barthes'ın deyişiyle, "düz-ölüm"e girmekteyiz burada. Başka bir deyişle, "simge, din ve töre dışı bir ölüm"e, "birdenbire gerçek ölüm'e dalışın” karanlığına (Barthes, 1999, s. 199). 
Fotoğraf 6. İç Savaş Mağduru Çocuklar, Foto: Finbarr O'reilly/Reuters (oanfotograflari-ntv.blogspot.com.tr, 12.02.2016)

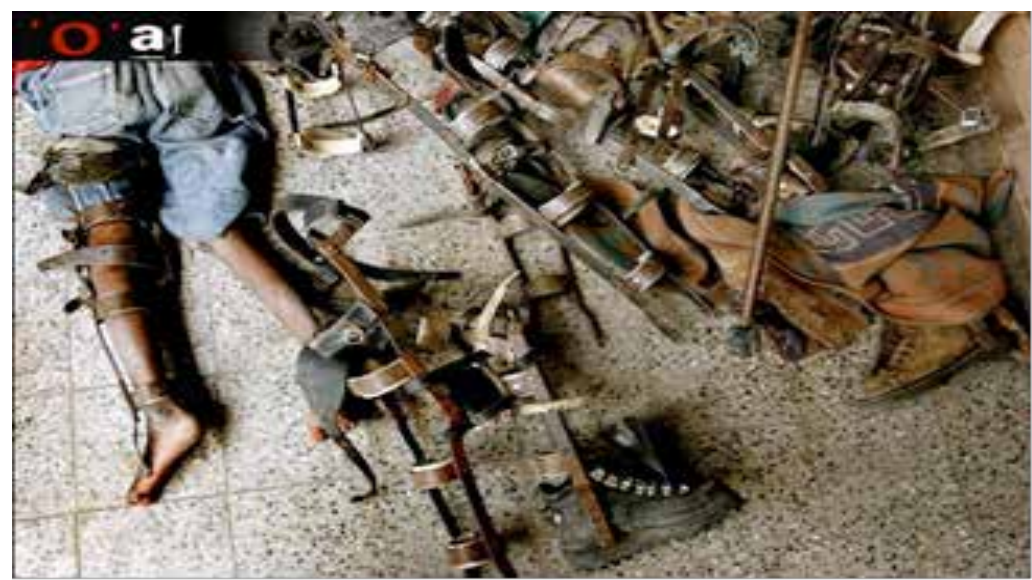

Düz ölüme giden yol, sadece bilinç sakatlanmasını değil, bazen sözcüğün düz anlamıyla fiziksel sakatlanmaları da içermekte. Fotoğraf 6'da, gerçek bacakların yerini alan protez bacaklar, ete kayışla tutturulmuş demir kasnaklar ve daha bir sürü "yaşam destek" ünitesiyle birlikte, yaşanan vahametin boyutlarını anlatmaya yetmekte gerçekten de. Üstelik üstteki fotoğraf karesinde yer alan dağınık nesne bolluğunun, Ortaçağ'ın azap verici işkence seanslarının cürüm aletlerini çağrıştırdığından bile söz edilebilir pekâlâ. Hele de görsel medyada vahşeti hissettirmek, onu anlamaya ve anlatmaya çalışmaktan bunca daha "muteber" bir eğilimken... Bu yüzden de savaşın nedeni önemli değildir, asıl önemli olan, dünya ekonomik sisteminin ne tür siyasal dümenler ve manevralarla yönetilmeye çalışıldığıdır. Başka bir deyişle, her "beş dakikada dünya silahlara on milyon dolar harcarken", "yüz altmış çocuğun açlıktan ya da iyileştirilebilir hastalıklardan dolayı ölmesidir" (Galeano, 2008, s. 69). Takdir edilmelidir ki, tüm bunları artık etkileyici bir tek fotoğraf karesiyle hissettirmenin olanağı yoktur. Üstelik dünya kamuoyunun kirli gerçekleri görebilmesini önleyen rıza üretme mekanizmaları her an devrededir ve en acı olanı da, egemen çokuluslu medya kuruluşlarının savaşın kabullenilebilir bir "gerçeklik" olduğuna dair yaratmaya çalıştıkları sözde-kanaat toplumunun sessizliğinin her şeyin önüne geçmiş olmasıdır. Berger'in yukarıda değindiğimiz dehşetin çifte şiddetinin etkisi dediği şeye ilaveten, Hobsbawm bunu, savaşta kamuoyunun üstlendiği roldeki değişime dikkati çekerek "CNN etkisi" şeklinde adlandırmaktadır (2007, s. 26). Savaşla ilgili malumat akışı üzerinde eskiye oranla çok az hükümet kontrolü bulunduğunu belirten Hobsbawm, "savaşı, halkın onu meşru ve haklı görmesini sağlayacak biçimde sunmak yaşamsal öneme sahiptir" (2007, s. 27) diye yazmaktadır. Söz konusu meşruiyet -bekleneni vermediği zamanlarda -, genellikle görsel medya metninin dilinin eklektik biçimde kurgulanmasıyla sağlanmakta olup, bu biçimiyle eklektizm, tam olarak anlam katmanlarının ve duyumların parçalanmasına dayanır. 
Söz konusu parçalanma ise, Harvey'in deyimiyle, "çağdaş genel kültürün başlangıç noktasıdır" (2006, s. 108). Bakışın ısrarı kesintiye uğratılığında, "görme"yi geçerli kılan anlamsal çerçeve de dağılmış olur. Sonrasında gelen yüzeysel algılama ise, yüze giydirilmiş bir maskedir sadece. Çağdaş popüler kültürün yıkıcılığı da tam olarak buradan gelir. Çünkü "maskeleme, yalnızca postmodernizmin eklektik alıntılama eğiliminden değil, yüzeylere olan açık bir hayranlıktan da kaynaklanır" (Harvey, 2006, s. 109). Yüzeye hayranlığın algılama açısından ortaya koyduğu dolaysız sonuca gelince; toplumsal gerçekliğe yönelik eksik bilgiyle donanmış olmanın getirdiği muhakeme yetersizliği ve duygusal bir kırılganlıktır. Sonuç olarak, her ikisi de mevcudu kabullenmeyi belirgin biçimde kolaylaştırdıkları içindir ki, görülmemiş ölçüde yıkıcıdırlar.

Fotoğraf 7. Suriye İç Savaşı'ndan Bir Kare, 21.01.2014 (https://www.aa.com.tr, 20.12.2015)

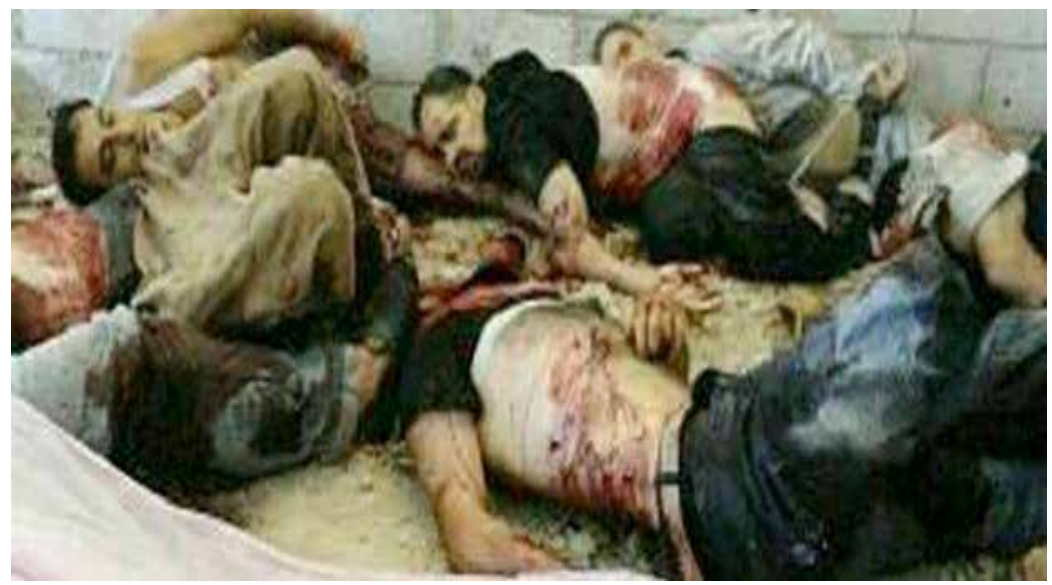

Post kolonyal medya çağında, İrfan Aktan'ın da dediği gibi (2014), "ölen, dışlanmıştır, geriye kalan ölü canlar da 'aşırı uç' olarak kenara iteklenmiştir. Artık mevzubahis olan, ölenlerin, kalanların hafızasında bıraktığı izdir." Aktan'ın sözünü ettiği izleri şimdiye kadar belki de Fotoğraf 7'deki görüntüler ölçüsünde etkili biçimde sunamamıştır hiçbir kare. Yan yana, üst üste, duygusuzca, barbarca, özensizce balık istifi yapılmış cesetler, sadece kültürel nazardan değil, aynı zamanda insanlık ailesinin en asgari içerimlerinden bile dışlanmış ve kovulmuşlardır. Dahası, bu kareyi içerdiği olası siyasal boyutlarıyla birlikte okuduğumuzda, mevcut görüntüye, Berger'in "ölüyle ders verme" (2015, s. 23) dediği kanibalist bir diplomasinin, emperyalizmin acımasız suretinin eşlik ettiği görülür. Egemenin öldürerek, yok ederek, kıyımdan geçirerek verdiği ürkütücü tarihsel dersin her devirdeki mukaddem cümlesi ise hiç kuşkusuz "aşağılamak" fiilinde bulmakta karşılığını. 2014 yılı Ocak ayında Anadolu Ajansı'nca Türkiye kamusal alanına servis edilen dehşet görüntülerinin herhangi bir mozaiklemeye gerek duyulmadan sunuluşu, mutlak voyeurist bir tavra da resmi bir onayın 
verilişini içermektedir alttan alta. Gizemli ölüm anına masumane biçimde tanıklık etmekten daha farklı bir güdüdür bu. Mahremiyeti fütursuzca teşhir edilen ölü ve savunmasız beden dikizlemesinin utanç vesikasını... Öte yandan, ıstırap anı ile yüzleşmeyi güçleştiren bir başka yönü de vardır bu tür fotoğrafların. Berger'i izleyerek söylersek, genellikle "bizim adımıza yürütüldüğü" söylenen ve "fiilen müdahale etmemizi mümkün kılacak" hiçbir yasal gerekçeye sahip olmadığımız bu savaşlara yönelik farkındalığımız, bizatihi savaş fotoğraflarının içerdiği dehşetin çifte şiddetiyle yıkıma uğratılmıştır (2015, s. 52). Biz izleyicilerin, ölüm gerçeğine yabancılaşmamızın ve mutat edilgenliğimizin yanı sıra, bu tür fotoğraflar karşısında anlamlı tepkiler veremeyişimizin nedenlerinden birisi de budur. Fotoğraf 7'nin içerdiği mizansende birer et yığını olarak sunulan ölü beden parçalarından yansıyan bir diğer uğursuz ayrıntı da, kuşkusuz ölen kişilerin mahremiyetlerini açıkta bırakan çıplak vücut bölgeleridir. Özellikle karenin üst orta kısmında yüzükoyun yatmakta olan adamın görüntüsü, belirgin biçimde nekrofilik (ölü sevici) bir anlama sahiptir ve dahası, bu anlamsal kesit, kadrajın bütünlediği diğer ayrıntılarla birlikte yorumlandığında, fotoğrafta adeta "postmortem" bir orji (cinsel birleşmeye dek varan taşkın eğlence) ayinine yönelik imalı göndermeler mevcuttur.

\section{Sonuç}

Sonuç olarak, günümüzde ölümün kendisi ve ölü beden yeni iletişim teknolojilerinin sunduğu devrim niteliğindeki olanaklarla artık daha da "görünür" hale gelmiştir. Elbette ölüm ve ölü beden gösterilebilir, ancak bunu yapmadan önce, olaya sonuç odaklı her türlü teşhirci, kışkırtıcı dilsel sunum biçimini öteleyen ve her bir bireyin saygınlığı ve kutsallığı ilkesinden yola çıkan deontolojik etik tutum açısından yaklaşmak gerekir: Her bir kişinin saygınlığı, adalet, insan onuru, mahremiyet, vb. Çünkü ölüm, şiddet ya da vahşet, çağın egemen görsel merkantilist ufkuna (ilkel bir ticari/iktisadi güdü anlamında) inat, alınıp satılacak şeyler değildir. Bu fotoğrafı niçin ve kimin için çektiğimiz ve hangi gerekçeyle yayımladığımız büyük önem arz etmektedir. İkinci olarak, foto muhabirleri veya kameramanlar bu tür görüntüleri kaydedip yaymadan önce, kendilerini fotoğrafladıkları kişilerin yerine koymalıdırlar. "Ben veya sevdiklerim, yakınlarım bu durumda olsalar, savunmasız bedenimin/bedenlerinin bu şekilde sunulmasına razı olur muydum?" diye kendilerine sormalıdırlar. Kuşkusuz, bu görece masum önlemlerin işe yarayabilmesi, haber medyasının ekonomi politiğinin böyle bir özgürlüğe alan açmasına bağlıdır ki, bunun olabilmesi hiç de zannedildiği kadar kolay değildir. Meselenin görsel algılama paradigmamızda yarattığı değişimlere gelince; Walter Benjamin fotoğrafın icadıyla değişen gerçeklik algısını yaklaşık yarım asır önce, uzaktaki ya da ölmüş sevilenlerin anılarının canlı tutulma çabası açısından değerlendirip, resmin kült değerinin son sığınağı olarak insan yüzüne vurgu yapmıştı. Temelde atmosfer (aura) diye adlandırılan öğeydi sözünü ettiği şey. Aura, "eski fotoğraflarda, bir insan yüzünün gelip geçici ifadesinden bizlere son kez el sallamaktaydı" onun deyişiyle (Benjamin, 2012, s. 53, 60). Söz konusu görsel algılama biçimi, hiç şüphesiz bugün gelişen ve etkin biçimde kullanılan 
yeni iletişim ve medya teknolojileri nedeniyle, Benjamin'in bıraktığı noktada değildir. Ölüm hala "hayatın ötekisi"dir, ancak buna bir de öteki'lerin hayatına gösterilen hoyratça duyarlıık eklenmiştir. Özellikle yoksul ve sömürgeleştirilmiş ülkelere mensup insanların ölümleri ve ölü bedenleri ölümün ve bedenin aura'sı, kutsallığı ve mahremiyeti hiçe sayılarak tecimsel bir meta, bir tür teşhir ürünü gibi cömertçe sergilenebilmektedir. Acının bu pornografik sunumu ve marazi temsil biçimiyle birlikte, artık ölüm de beden de kutsallı̆ı̆ı yitirmiştir. Özellikle gazetelerin üçüncü sayfa haberlerinde, televizyon haber bültenlerinde, sinema ve dizi filmlerde, en belirgin biçimde de savaş haberciliğinde bu eğilimi tüm çıplaklığıyla gözlemlemek mümkündür. Üstelik bu süreçte yayıncılık etiğinin selameti açısından ciddi rizikolar da mevcuttur: Geleneksel kurumsal haber medyasına ilaveten, sıradan yurttaşlar da teknolojinin olanaklarından yararlanıp, özellikle sosyal medya mecralarında ölümü ve ölü bedeni çoğunlukla editöryel bir denetim süzgecine takılmadan sorumsuzca ve bilinçsizce teşhir etmekten geri durmamaktadırlar. Üstelik bu sonuncu gelişmenin, nefret söylemlerine çanak tutmak, dezenformasyonu körüklemek, manipülatif içerikler yayarak kamusal algıyı çarpıtmak, vb. daha başka yıkıcı sonuçları da mevcuttur. Başta söylediğimizi burada tekrar edersek, acının dramaturjisinin istismara açık bir kurgu olmadan düşünülemez hale getirilmesi, konunun daha uzun bir süre medyanın sorunlu toplumsal gerçeklik algısı ve temsili bağlamında tartışımasını gerekli kılacağa benzemektedir.

\section{Kaynakça}

Adorno, T. W. ve Horkheimer, M. (2010). Aydınlanmanın Diyalektiği. (M. Tüzel, Çev.). İstanbul: Kabalcı Yayınevi.

Aktan, İ. (18 Mayıs 2014). Ölünüz, gerisiyle biz meşgul oluruz. Radikal. http:// www.radikal.com.tr/radikal2/olunuz-gerisiyle-biz-mesgul-oluruz-1192462/

Amery, J. (2015). Suç ve Kefaretin Ötesinde. (C. Ener, Çev.). İstanbul: Metis Yayıncilık.

Bauman, Z. (2012). Ölümlülük, Ölümsüzlük ve Diğer Hayat Stratejileri. (N. Demirdöven, Çev.). İstanbul: Ayrıntı Yayınları.

Barthes, R. (1992). Camera Lucida. (R. Akçakaya, Çev.). İstanbul: Altıkırkbeş Yayın.

Barthes, R. (1999). Yazı ve Yorum. (T. Yücel, Çev.). İstanbul: Metis Yayıncılık.

Benjamin, W. (2012). Pasajlar. (A. Cemal, Çev.). İstanbul: Yapı Kredi Yayınları.

Berger, J. (2015). Bir Fotoğrafı Anlamak. (B. Eyüboğlu, Çev.). İstanbul: Metis Yayıncılık.

Canetti, E. (2006). Kitle ve iktidar. (G. Aygen, Çev.). İstanbul: Ayrıntı Yayınları. 
Cheviron, N. T. (2014). Televizyon ve Içimizdeki Kutsal. İstanbul: Ekslibris Yayıncılık.

Debord, G. (2006). Gösteri Toplumu. (A. Ekmekçi ve O. Taşkent, Çev.). İstanbul: Ayrıntı Yayınları.

Galeano, E. (2008). Biz Hayır Diyoruz. (B. Kale, Çev.). İstanbul: Metis Yayınları. Gürbilek, N. (2001). Kötü Çocuk Türk. İstanbul: Metis Yayınları.

Harvey, D. (2006). Postmodernliğin Durumu. (S. Savran, Çev.). İstanbul: Metis Yayınları.

Hobsbawm, E. (2007). Yeni Yüzyılın Eşiğinde. (I. Yıldız, Çev.). İstanbul: Yordam Kitap.

Inceoğlu, Y. ve Çoban, S. (2014). Ötekileştirme Sürecinde Medyanın Yeri. Y. Inceoğlu ve S. Çoban (Ed.), Azınlıklar, Ötekiler ve Medya içinde (50-102). İstanbul: Ayrıntı Yayınları.

Kete, N. (2011). Yoksulluk, Mahremiyet ve Ölüm İlişkisini Medya Üzerinden Okumak. H. Köse (Ed.). Medya Mahrem içinde (61-83). İstanbul: Ayrıntı Yayınları.

Mestrovic, G. S. (1999). Duyguötesi Toplum. (A. Yılmaz, Çev.). İstanbul: Ayrıntı Yayınları.

Onay, i. (2013). İslamiyet'ten Önceki Türklerde, Cenaze ve Defin İşlemlerinde Uygulanan Gelenekler ve Bunların Amaçları. International Journal of Social Science, Volume 6, Issue 3, 479-490.

Sartori, G. (2006). Görmenin Iktidarı. (G. Batuş ve B. Ulukan, Çev.). İstanbul: Karakutu Yayınları.

Schmid, W. (2015). Sakin Olmak. Yaşlanırken Kazandıklarımız. (T. Bora, Çev.). İstanbul, İletişim Yayıncılık.

Silverman, K. (2006). Görünür Dünyanın Eşiği. (A. Onacak, Çev.). İstanbul: Ayrıntı Yayınları.

Sontag, S. (2004). Başkalarının Acısına Bakmak. (O. Akınhay, Çev.). İstanbul: Agora Kitaplığı.

Şahin, H. (2014). Hodri Medya. İstanbul: Ka Kitap.

Topuz, H. (2003). Türk Basın Tarihi. İstanbul: Remzi Kitabevi.

Tosun, G. E. (2007). Çocuklar ve Çocuk Haklarının Medyada Temsili. S. Alankuş (Haz.), Çocuk Odaklı Habercilik içinde (172-195). İstanbul: IPS Illetişim Vakfı Yayınları.

Williams, K. (1998). Gerçeklerden Daha Önemli Bir Şeyler: Savaş Haberciliğinde Etik Sorunlar. (N. Türkoğlu, Çev.). Medya ve Gazetecilikte Etik Sorunlar içinde (188-207). A. Belsey ve R. Chadwick (Ed.). İstanbul: Ayrıntı Yayınları. 
https://www.aa.com.tr. Erişim 20 Aralık 2015.

http://www.aksiyon.com.tr/karakutu-dunya/suriye-ic-savas-basladi-can-kaybi-20bini-asti_533355. Erişim 9 Aralık 2016.

http://dunya.milliyet.com.tr. Erişim 15 Haziran 2014.

http://www.fotoevidence.com/manu-brabo. Erişim 10 Şubat 2016.

http://www.ledevoir.com/international/actualites-internationales/400935/damaspret-a-favoriser-un-acces-humanitaire. Erişim 8 Şubat 2016.

http://levracdupasseur.tumblr.com. Erişim 12 Şubat 2016.

www.ntv.com.tr. Erişim 10 Şubat 2016.

oanfotograflari-ntv.blogspot.com.tr. Erişim 12 Şubat 2016. 